AUTHOR:

Daniel Phiri',

AFFILIATION:

${ }^{1}$ History and Civic Education teacher, Malambwa Secondary School. He is also a Master of Arts History student at the University of Zambia

EMAIL:

danielphiri14@yahoo.com

DOI: https://dx.doi. org/10.18820/24150509/

SJCH45.v2.5

ISSN 0258-2422 (Print) ISSN 2415-0509 (Online)

Southern Journal for

Contemporary History

2020 45(2):104-124

PUBLISHED:

30 December 2020

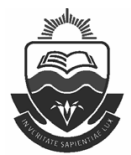

Published by the UFS http://journals.ufs.ac.za/index.php/jch (C) Creative Commons With Attribution (CC-BY)

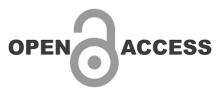

\section{THE ROLE PLAYED BY AFRICANS IN THE BRITISH WAR EFFORT IN ABERCORN DISTRICT, NORTHERN RHODESIA DURING THE FIRST WORLD WAR}

\begin{abstract}
The First World War broke out on 28 July 1914 as a European war between the Triple Alliance and the Triple Entente. ${ }^{1}$ African colonies soon joined the fighting on the side of their respective colonial masters. It was in this context that Northern Rhodesia (today's Zambia) entered the war on the side of imperial Britain against Germany. In Northern Rhodesia, the war was confined to the most northerly region bordering German East Africa (Tanzania), particularly in Abercorn (Mbala) district. The British were faced with a crucial situation in the district that they incorporated the local Africans to fight the Germans. As such, the indigenous people's land in Abercorn became a battlefield. While existing studies have focussed on the part played by African porters during the First World War, scholars have largely overlooked the role played by African combatants, food suppliers, spies, and postal runners on the warfront. Thus, the article attempts to bring to the fore various roles played by Africans in Abercorn during this Great War. In this manner, the article demonstrates how the local people in Abercorn played a decisive role in determining the Allied victory by 25 November 1918 in the district in particular and in Northern Rhodesia and German East Africa in general.
\end{abstract}

Keywords: Abercorn (Mbala), Northern Rhodesia (Zambia), Combatants, Spies, Porters, Postal Runners, Food Production and Supplying.

1 The Triple Alliance was a military pact of Germany, Austria-Hungary and Italy, the nucleus of the Central Powers during the First World War. The Triple Entente was a defensive pact signed by Britain, France and Russia, nucleus of the Allied Nations in the First World War. By 1914, the Triple Alliance and Triple Entente divided Europe into two armed blocs. More on this, see, B Walsh, Modern World History (London: John Murray, 1996), pp.5-6. 
Phiri / The role played by Africans in the British war effort in Abercorn District, Northern Rhodesia during the First World War

\section{INTRODUCTION}

Studies examining the role played by Africans during the First World War in various regions of the African continent have largely been confined to porterage. ${ }^{2}$ Few studies have investigated other efforts made by Africans to the belligerent nations during the war. ${ }^{3}$ Studies which have attempted to investigate war efforts by local Africans during the Great War of 1914-18, have overlooked other significant roles played by Africans, which include those engaged as combatants on the war front, food suppliers, spies, and postal runners. ${ }^{4}$

On the continent, Africans participated in the First World War through three major theatres: the West African, South West Africa, and East African. The latter campaign of the Allied powers against the Germans in Tanganyika was the longest episode of the war because the German Army Commander, General Paul Emil Von Lettow Vorbeck, adopted a guerrilla strategy drawing several areas into war in which Abercorn, Northern Rhodesia's northerly district, got involved. Academics who have studied the war on this theatre such as Anderson Ross shrouded the local people's war efforts. Ross rightly observed that the imperial army faced food and transport challenges during the war. However, he unduly played down Africans' role in overcoming these challenges by stating that the problems of food and transport were only solved by widespread construction of roads and use of motor vehicles from Nyasaland. ${ }^{5}$

In Uganda, Africans worked as porters during the war, and this created a shortage of labour on the farms in the villages. In his study, Geoffrey William Theodore Hodges contented that, Uganda contributed a total of about 190000 porters, arguably the largest number to the Allies during the

2 ME Page, "The War of the Thangata: Nyasaland and the East African Campaign, 1914-18", Journal of African History 19 (1), 1978 ; C Luchembe, "Ethnic Stereotypes, Violence and Labour in Early Colonial Zambia". In: S Chipungu (ed.), Guardian in Their Time, Experience of Zambians Under Colonial rule 1889-1924 (London: MacMillan, 1992), pp. 30-49.

3 Some works focused on the role played by African Christian mission-teachers during the First World War in East Africa, see, L Pirouet, "East African Christians and World War 1", Journal of African History 19 ( 1), 1978; E Yorke, "The Spectre of a Second Chilembwe: Government, Missions, and Social Control in Wartime Northern Rhodesia, 1914-18", The Journal of African History 31 (3), 1990; RV Pierard, "Allied Treatment of Protestant Missionaries in German East Africa World War 1", The African Journal of Evangelical Theolodgy 12 (1), 1993.

4 GWT Hodges, "African Manpower Statistics for the British Forces in East Africa, 1914-1918", Journal of African History 19 (1), 1978.

5 R Anderson, World War I in East Africa 1916-1918 (PhD, University of Glasgow, 2001), p. 1. 
East African campaign. However, he acknowledged that some carriers came from different parts of colonial Zambia. ${ }^{6}$

Similarly, in Nyasaland, a British protectorate, Africans worked either as carriers or soldiers during the war. Marvin Page observed that the local people in Nyasaland started rebelling against being recruited as porters. To prove his assertion, Page cited the Chilembwe uprising as an example of African dissent in the provision of war services. ${ }^{7}$ Despite this rebellion, colonial authorities started using excessive force to conscript Africans for war services.

Some Europeans and African farmers supplied foodstuffs to the army in Northern Rhodesia. Lewis Gann observed that during the war, farmers, both European and African, settled along the line of rail benefited from being suppliers of foodstuffs to the military. ${ }^{8}$ Chipasha Luchembe attempted to recognise the effort made by Africans in Abercorn district during the war. $\mathrm{He}$ observed that the British used North-Eastern Rhodesia to counter the Germans in Tanganyika during the Great War of 1914-18. ${ }^{9}$

One of the most recent works that captured other roles, which Africans played during the war was done by Jan-Bart Gewald. Gewald acknowledged that some Africans were recruited as soldiers. ${ }^{10}$ Although Gewald's work aimed at showing how the colonial state consolidated its administration in Northern Rhodesia by involving Africans in the war, it is one of the few studies that acknowledge Africans involvement in the First World War as combatants.

It is evident from the above studies that African participation in the First World War has been confined mainly to porterage. In addition, there is a lapse on the war efforts made by Africans in Abercorn district in the execution of the war by the British. It was at Abercorn that the war's last battle was fought two weeks after the cessation of fighting in Europe. Abercorn, a northerly district bordering Northern Rhodesia and German East Africa provided an arid expanse into the British colony of Northern Rhodesia, and the Allies' mineral-rich region of Katanga in the Belgian Congo. The Katanga had minerals such as copper which the Allied nations used for manufacturing ammunition for the war. Therefore, the capture of the Katanga by Germany implied a stifled supply of important war raw materials to the Allied forces, thereby giving an advantage to the Germans to win the war. Thus, this article

6 Hodges, "African Manpower Statistics for the British Forces in East Africa, 1914-1918", pp. 101-114.

7 Page, "The War of the Thangata: Nyasaland and the East African Campaign, 1914-18", p. 90.

8 G Lewis, A History of Northern Rhodesia: Early Days to 1953 (London: Chatto and Windus, 1964), p. 165.

9 Luchembe, "Ethnic Stereotypes, Violence and Labour in Early Colonial Zambia", pp. 41-42.

10 JB Gewald, Forged in the Great War: People, Transport and Labour, The Establishment of Colonial Rule in Zambia ( Leiden: African Studies Centre, 2015), p.117. 
Phiri / The role played by Africans in the British war effort in Abercorn District, Northern Rhodesia during the First World War

also seeks to highlight the role of the indigenous people towards the Allied victory in Abercorn by 25 November 1918. The crafting of this work was dependent much on primary sources from the Faith and Encounter Centre Zambia (FENZA), Livingstone Museum (LM), and the National Archives of Zambia (NAZ).

\section{AFRICANS AS COMBATANTS}

The engagement of local Africans by the British as soldiers during the war is illuminated through the three major battles they fought against the Germans in Abercorn: Battle for the British Overseas Military Administration (BOMA) site, Saisi, and Kasakalawe. The sections below discuss these battles in detail.

\subsection{The Battle of Abercorn BOMA}

As a BOMA, Abercorn was the centre of the enemy's interest for two major reasons. In the first place, General Lettow-Vorbeck devised a war tactic of distracting the Allied forces in Africa from the main theatre of the war in Europe. The Geman General wanted to distract the Allied countries in Africa from supplying their forces in Europe with colonial soldiers and resources. ${ }^{11}$ This was aimed at giving a chance to the Germans fighting in Europe to defeat the Allied powers as the latter could be cut off from colonial reinforcement. ${ }^{12}$ To achieve this, General Vorbeck planned to display guerrilla warfare in Allied nations' colonies. In the south of German East Africa (GEA), General Vorbeck considered Abercorn as a point of attracting the British forces in Northern Rhodesia into a war. ${ }^{13}$ This was done by launching episodic attacks on the district. The British responded by fortifying the district with combatants. In the second place, Abercorn provided a waterless landmass into the Allies region of Katanga which was rich in minerals like copper. Like stated in the introductory part, the Allied nations used copper for manufacturing munitions for the war. As such, the Germans were determined to seize the Katanga region. ${ }^{14}$ However, the seizure of the Katanga region by the Germans meant overriding Abercorn as it lay on the forefront passage into Northern Rhodesia and Belgian Congo mainland, either by land or lake Tanganyika. ${ }^{15}$

11 J McCracken, A History of Malawi, 1859-1966 (Rochester: James Murrey, 2012), p. 148.

12 EJ Yorke, Britain, Northern Rhodesia and The First World War: The Forgotten Colonial Crisis (New York: Macmillan, 2015).

13 Yorke, Britain, Northern Rhodesia and the First World War, p. 39; R Anderson, "Norforce: Major General Edward Northey; and the Nyasaland and North-Eastern Rhodesia Frontier Force, January 1916-1918", Scientia Militaria 44 (1), 2016, p. 48. Yorke, Britain, Northern Rhodesia and the First World War, p. 49.

15 H Strachan, The First World War in Africa (Oxford: Oxford Univesity Press, 2004), p. 127. 
Due to the above reasons, Abercorn experienced several attacks by enemy forces based in neighbouring GEA. The first German attack on Abercorn was on 5 September $1914 .{ }^{16}$ On that occasion, they were repulsed by the local force which the District Commissioner formed..$^{17}$ It is also important to appreciate that the force which first dislodged the Germans from the BOMA was dominated by local Africans aiding the few Europeans available. With the urge to take over Abercorn, the Germans launched a second assault on the fort in the early hours of 9 September $1914 . .^{18}$ The enemy started shelling from a distance although their artillery did not harm the British troops based at the BOMA due to the thick bush around the fort. From September onwards, the Germans remained within the vicinity of the district intending to seize it by force.

During these attempts by the Germans to annex Abercorn, British forces were on the defensive side of the war. This strategy was adopted because the initial British force had few soldiers and guns and needed more time to recruit Africans and train them on how to operate the firearms properly. ${ }^{19}$ However, the colonial masters were aware of the danger of training more Africans on how to utilise guns. While this was going on, reinforcement was sought from Kasama, and in the evening of 9 September 1914, Major Harry March Stennet arrived at Abercorn BOMA with troops. ${ }^{20}$ During the same evening, the Germans started shelling at the BOMA. ${ }^{21}$ Having been reinforced, the Allied forces responded to German gunfire with an offensive, and at once, the latter started receding across the border in disorder. ${ }^{22}$ During this operation, the Gemans had no casualties. However, two African soldiers were shot dead.

In November 1914, the Germans again entered the district through chief Zombe's chiefdom. This was a border territory with GEA. ${ }^{23}$ Fire-exchange ensued between the two arch-enemies in an area which eventually became

16 The Livingstone Museum (LM) 2/4/58/1 G69/1, Report of the work done by the Northern Rhodesia Police in the 1914-18 war, p. 4; The Northern Rhodesia Handbook (Lusaka: Northern Rhodesia Information Department, 1953), p.17.

17 National Achieves of Zambia (hereafter NAZ) A2/3/1 Loc 791/197, Correspondence from Northern Rhodesia Administrator Wallace to the secretary of the British South African Company, London, 4 September 1914.

18 V Brelsford, The Story of the Northern Rhodesia Regiment (Bromey: Galago, 1954), p. 30.

19 NAZ A2/3/4 Loc 794/198, Correspondence from the Administrator to the Secretary BSACo London, 26 February 1915; NAZ A2/3/4 Loc 794/198, Letter by Administrator Northern Rhodesia to the Secretary BSACo, London, 12 October 1914.

20 Brelsford, The Story of the Northern Rhodesia Regiment, p. 30.

21 Brelsford, The Story of the Northern Rhodesia Regiment, p. 30.

22 NAZ A2/3/1 Loc 791/197, Correspondence from Northern Rhodesia Administrator Wallace to the secretary of the BSACo London, 4 September 1914.

23 Interview: Author with C Sikazwe, Chief Zombe, Mbala, 27 March 2019. 
Phiri / The role played by Africans in the British war effort in Abercorn District, Northern Rhodesia during the First World War

known as "Malwilo". ${ }^{24}$ It was located on the north-west of the BOMA, approximately 27 kilometres from the main British garrison.

When the war intensified on this front, the Allied troops were compelled to withdraw from their posts. In 1915, the Allied soldiers who were in Kaseshya, another border area within chief Zombe, retreated towards their garrison at the BOMA due to German gunfire. By December 1915, the British recruited more than 4000 African combatants who fought alongside about 460 Europeans in Abercorn. ${ }^{25}$ Despite this number, the Germans advanced further towards the BOMA between 1915 and 1917. In order to block the invading Germans, the British fortified Zombe village which lay between the two warring forces. The fortified village was located 20 kilometres away from the BOMA, and two kilometres from the GEA border. ${ }^{26}$ The fortification was done by setting up a military camp in a mountain locally called Kalwezi. After the war, the local people renamed it as "Kamba", a local corruption of the English term "camp". ${ }^{27}$ The mountain was given this name because the Allied forces had camped there during the war. Despite fortifying Zombe village, the Germans pressed on, while the Allied forces went on the defensive. The latter took up positions from Abercorn prison. ${ }^{28}$

As the fighting went on, African prisoners who were incarcerated at Abercorn prison rose to support their colonisers. Although being dangerous and already serving sentences, African inmates braved the gunshots to fetch water from Lake Chila for troops stationed at the prison. ${ }^{29}$ Villagers from the nearby places also took water to the prison at night when the enemy could hardly see them. ${ }^{30}$ This was done out of the local people's own desire and patriotism to support the pressed Allied soldiers. This was a significant contribution on the part of Africans because the troops needed water for various uses such as drinking and preparation of food. In addition to drawing water, African prisoners dug trenches, cut poles and fenced the garrison with barbed wires to defend the district. ${ }^{31}$

$24 \quad$ Interview: Author with J Sinyangwe, Mbala, 30 March 2019.

25 NAZ ZA/7/1/3/9 Box 88, Abercorn sub-District Annual Report the year ending 31 March 1915, 1 April 1915, p. 12; M Mbewe, "Mbala Meander: World War 1 fortifications in Mbala", Lowdown Magazine 20 (11), 2014, p. 29.

26 Mbewe, "Mbala Meander: World War 1 fortifications in Mbala", p. 29.

27 Interview: Author with C Sikazwe ; Interview: Author with G Simusokwe, Secretary of Chief Tafuna, Mpulungu, 29 March 2019.

28 NAZ KTN 1/1, 93, Abercorn District Notebook Volume II, H, p. 8.

29 NAZ A2/3/2 Loc 792/197, Report on the Affairs of Abercorn and Tanganyika District covering 29 September 1914 to 30 December 1914 by the District Commissioner of Abercorn Sergeant Chesnaye to the Administrator Northern Rhodesia, 31 December 1914.

30 LM 2/4/58/1 G 67/1, Copy of the description of the work done by the Northern Rhodesia police in the 1914-18 war, p. 4.

31 NAZ KTN 1/1, 93, Abercorn District Notebook, Volume II, H, p. 8; National Museums Board, First World War in Northern Rhodesia: Experiences of the Askari-foot Soldiers and Tenga- 
The Allies' defensive strategy operated on the premise that when the enemy's ammunitions were finished, only then would they launch their attack. It was during this time of pushing back the Germans that local prisoners became involved in the actual fight. The indigenous convicts overlooked their punishments by carrying the maxim gun and bullets for the fighters. ${ }^{32}$ This was done under gunfire from the retreating Germans. Despite the enemy firepower, African prisoners and fighters repelled the Germans from the BOMA to the eastern border of the district.

Another notable operation during which Africans were actively engaged in combat in defence of Abercorn was the attack of 17 March 1915 near Chipogoma village. On this occasion, Allied soldiers under Lieutenant (LT.) James Joseph McCarthey were caught unaware by enemy fire. Most of the soldiers had been sent on special duties, while others were playing the game of piquet, famous among Allied troops during the First World War. ${ }^{33}$ The commander remained with only about 50 African soldiers and five European policemen. With a strength of five Europeans and more than 100 askari, the Germans moved into Chipongoma village. ${ }^{34}$ At once, the Germans seized the headman's house and began shooting at local people indiscriminately. ${ }^{35}$ Following the killing of eight unarmed villagers, LT. McCarthey gave orders to counter the assault. ${ }^{36}$

During the above encounter, shooting between the two arch parties persisted with neither of them retreating from their firing positions. The Belgians who were incorporated in the war by the British in defence of Abercorn were also patrolling in the vicinity. They were then called upon by LT. McCarthey for reinforcement. It was after this reinforcement that the enemy backed down in the direction of the border. This encounter left one British officer and three African soldiers dead. ${ }^{37}$ Two Belgians were also wounded. ${ }^{38}$ On the other hand, four dead bodies of German forces were found at the

Tenga War-Carriers (Lusaka: Ministry of Tourism and Arts, 2018).

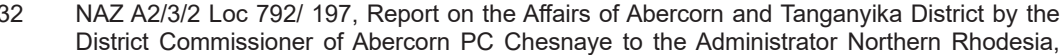
31 December 1914.

33 NAZ A2/3/4 Loc 794/198, Report by HM Stennet to the Chief Staff Officer, Salisbury, 18 March 1915.

34 NAZ A2/3/4 Loc 794/198, Report by HM Stennet to the Chief Staff Officer Salisbury, 18 March 1915. Askari is a Swahili plural term for African soldiers.

35 NAZ A2/3/4 Loc 794/198, Report by HM Stennet to the Chief Staff Officer Salisbury, 18 March 1915; Interview: Author with J Sinyangwe.

36 NAZ A2/3/4 Loc 794/ 198, Report by HM Stennet to the Chief Staff Officer Salisbury, 18 March 1915; Interview: Author with J Sinyangwe.

37 NAZ A2/3/4 Loc 794/ 198, Telegram from Wallace Administrator to Monomutapa, 30 March 1915.

38 NAZ A2/3/4 Loc 794/ 198, Telegram from Wallace Administrator to Monomutapa, 30 March 1915. 
Phiri / The role played by Africans in the British war effort in Abercorn District, Northern Rhodesia during the First World War

scene: one European and three askari. ${ }^{39}$ Map I illustrates significant fighting scenes during the Battle for Abercorn BOMA.

\section{Map I: Major Scenes of Fighting During the Battle of Abercorn BOMA}

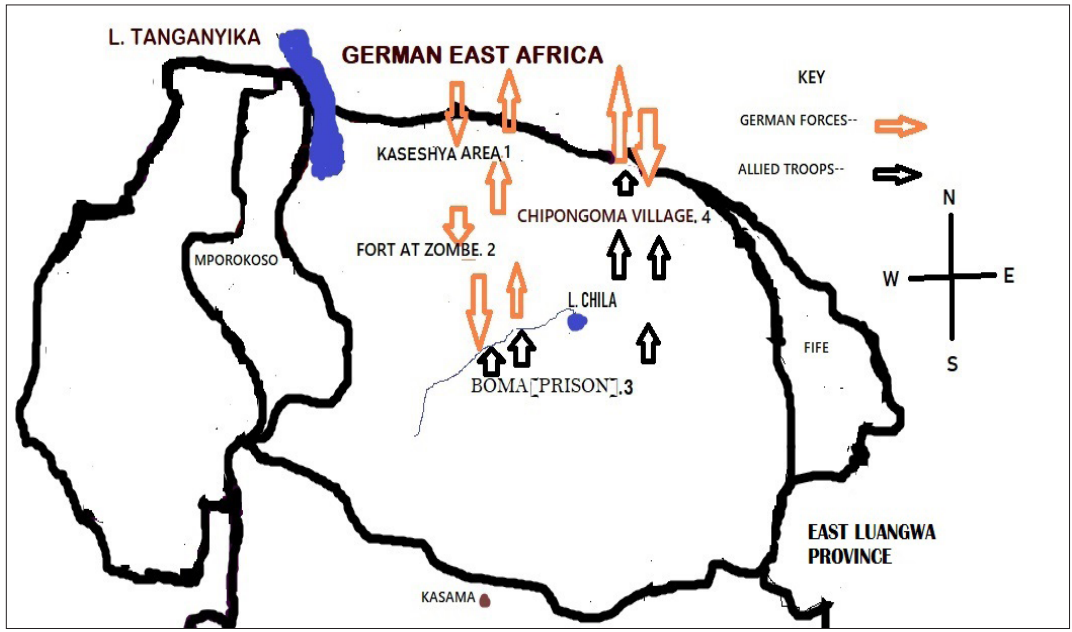

Source: Adapted from, Yorke, Britain, Northern Rhodesia and the First World War, p. 69.

\subsection{The Battle of Saisi}

As the Germans attacked Abercorn BOMA, they also cut telegraph wires which connected it to Fort Fife. This sabotage of telegraph wires stifled communication between the two forts. British military authorities soon realised that there was a need for a garrison between Abercorn and Fife that could prevent the Germans from having a direct access route to Kasama depot for supplies. ${ }^{40}$ Due to these reasons, colonial authorities built a garrison between Fort Abercorn and Fife. This garrison was built at a farm (known as Jericho by the Germans) in the Valley of Saisi River. It was located 84 kilometres south-west of the Abercorn BOMA. ${ }^{41}$

39 NAZ A2/3/2 Loc 792/ 198, Report by HM Stennet to the Chief of Staff Officer Salisbury, 18 March 1915; Interview: Author with J Sinyangwe.

40 LM 2/4/58/1 G67/1, Copy of the description of work done by the Northern Rhodesia police in the 1914-18 war, p.7.

41 The Bulawayo Chronicle, 13 August 1915; Zambia Daily Mail, 24 November 2019. 
Situated on the more direct route to Kasama depot, Fort Saisi experienced several attacks from the enemy for about six months in 1915. On 22 June 1915, the Germans attacked Manika village which was located 3 kilometres north-east of Fort Saisi but were repulsed by an Allied Force of 25 African soldiers and one European officer. ${ }^{42}$ Nevertheless, the Germans made another effort to take over the fort on 28 June $1915 .{ }^{43}$ On this occasion, too, they were repelled by the Allied powers. During this encounter, Allied forces suffered a loss of three policemen, two Africans and one European. ${ }^{44}$ This attests to the fact that Africans were actively engaged as fighters in Abercorn during the war, and not merely as porters. ${ }^{45}$

After the above encounter, British commanders at Fort Saisi became complacent. To their surprise in the early hours of 29 June 1915, the Germans attacked Saisi garrison. Due to the foggy weather, it was difficult for the Allied forces to notice the enemy's presence in the vicinity. As such, the Germans surrounded the garrison without a lot of difficulties. After cutting the communication wire that connected Saisi with Abercorn, the enemy started the onslaught on the fort at 06: 45 hours and made determined effort to dislodge the Allied troops from Saisi. ${ }^{46}$ Throughout the day, there was fireexchange at Fort Saisi between the Allied troops and the Germans.

Meanwhile, the cutting of the telegraph cable that connected Abercorn signified the enemy's attack at Saisi; hence, reinforcement was sent by Abercorn garrison. In the evening of 29 June 1915, a party of Allied forces from Abercorn arrived behind the enemy's position. The strength of the reinforcement was 22 Europeans of the British South African Company (BSAC) policemen and 414 African soldiers, the majority of whom were from within Abercorn. ${ }^{47}$ Africans of Abercorn who were recruited as soldiers were distributed in all the forts of the district because they knew the topography of the area better than Africans from other districts. ${ }^{48}$ Throughout the night of 29 to 30 June 1915, all that could be heard at the fort were gunshots. By dawn, the enemy started retreating from the fort. ${ }^{49}$ After the cessation of shelling, the

42 The Bulawayo Chronicle, 13 August 1915.

43 NAZ A2/3/4 Loc 794/ 198, Copy of telegram from the Commandant to the Administrator Livingstone, by runners, 9 July 1915.

44 NAZ A2/3/4 Loc 794/198, Correspondence sent by administrator to the Secretary BSACo London, 13 July 1915.

45 Luchembe, "Ethnic Stereotypes, Violence and Labour in Early Colonial Zambia", p. 41.

46 NAZ A2/3/4 Loc 794/198, Copy of telegram from the Commandant to the Administrator Livingstone, 9 July 1915.

47 NAZ A2/3/4 Loc 794/198, Report by Hodson to the Chief Staff Officer Salisbury, 30 June 1915 , p. 1.

48 NAZ A2/3/4 Loc 794/198, Report by Hodson to the Chief Staff Officer Salisbury, 3 June 1915; Interview: Author with S Edson, Mbala, 2 April 2019.

49 NAZ A2/3/4 Loc 794/198, Report by Hodson to the Chief Staff Officer Salisbury, 30 June 1915, p. 1. 
Phiri / The role played by Africans in the British war effort in Abercorn District, Northern Rhodesia during the First World War

Allied forces lost one European and three Africans. ${ }^{50}$ The Germans had 15 Europeans killed and another 11 wounded. In addition, 19 of their askari were killed while many others were wounded. ${ }^{51}$ Map II illustrates the battle of Saisi.

\section{Map II: The Battle of Saisi}

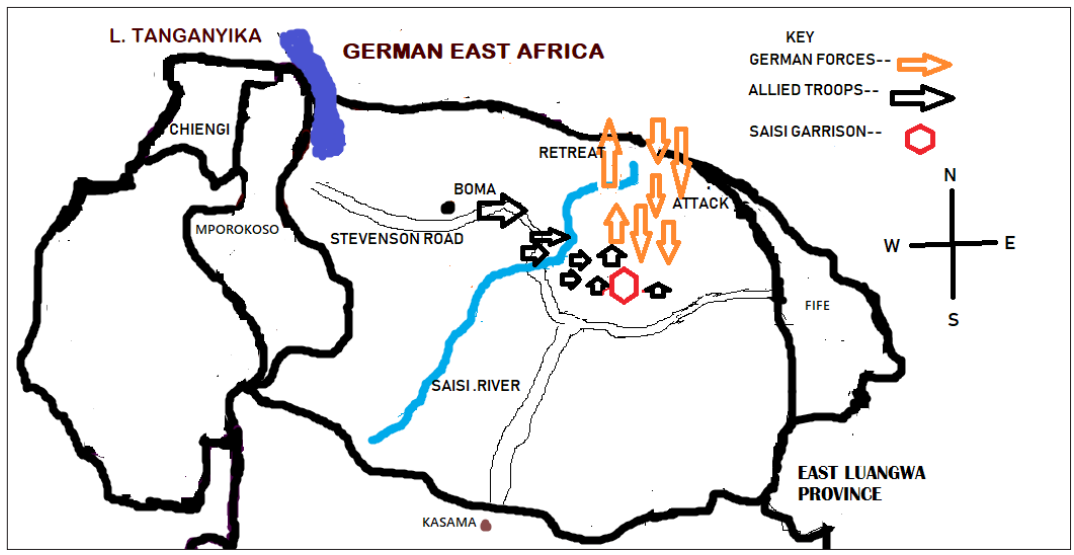

Source: Adapted from, Brelsford, The story of Northern Rhodesia Regiment , p. 38.

\subsection{The Battle of Kasakalawe}

Kasakalawe was another battle where a good number of African combatants were engaged by the British against the Germans. It was located about 17 kilometres north-west of Abercorn BOMA, on the shores of Lake Tanganyika. The area was surrounded by several villages and was a host to the storage facilities of the African Lakes and Transcontinental Telegram Company. ${ }^{52}$ On the other hand, the Germans in East Africa thought that Kasakalawe was a major military supply station of the British in Abercorn. ${ }^{53}$ The Germans aimed at destroying the purported British supply station to suffocate the strength of the Allied forces in the district. For this reason, the Germans decided to attack Kasakalawe.

50 NAZ A2/3/4 Loc 794/198, Report from colonel Hodson to the Chief Staff Officer Salisbury, 30 June 1915, p. 3; The Bulawayo Chronicle, 13 August 1915.

$51 \quad$ LM 2/3/2 9, This box contain pieces of newspapers, one with the title "N.R Rifles in Action; Taking of German Stockade"; The Bulawayo Chronicle, 13 August 1915.

52 NAZ A2/3/1 Loc 793/ 197, Correspondence from Lieutenant Colonel Stennet to the Commandant Northern Rhodesia Police Force Livingstone, 19 November 1914.

53 NAZ A2/3/1 Loc 791/197, Report on Abercorn to the Commandant General Northern Rhodesian Forces Salisbury, 28 November 1914. 
On 20 November 1914, German forces based at Bismarckburg in southern Tanganyika landed at Kasakalawe via Lake Tanganyika using a ship. ${ }^{54}$ After receiving intelligence reports from the local people about the enemy's presence in the area, the Allied forces based at Abercorn BOMA, headed for Kasakalawe with a force of 420 local men and a considerable number of Europeans under Major Stennet. ${ }^{55}$ As this force reached the area, the Germans attacked them to which they responded with the corresponding firepower.

The Germans quickly brought in more soldiers for reinforcement by ship from Bismarckburg. After the arrival of this buttressing party, the Allied soldiers retreated from Kasakalawe to their base at Abercorn BOMA. This military encounter left one African soldier dead and several others wounded. One German soldier was shot dead by an African soldier. ${ }^{56}$ The Germans remained in control of Kasakalawe for about 24 hours. On 21 November 1914, German troops returned to Tanganyika leaving extensive damage in the area through looting. Among items they took were communication wires of the African Transcontinental Company. ${ }^{57}$ Later during the same day of 21 November 1914, Allied forces in the company of African troops returned to Kasakalawe. Unfortunately, all they found was destroyed property and ashes of burnt villages as the Germans had already left. ${ }^{58}$ Map III depicts the battle of Kasakalaw.

$54 \quad$ NAZ A2/3/1 Loc 791/197, Report on Abercorn to the Commandant General Northern Rhodesian Forces Salisbury, 28 November 1914; Times of Zambia, 20 November 2018.

55 NAZ A2/3/1 Loc 791/197, Report on Abercorn to the Commandant General Northern Rhodesian Forces Salisbury, 28 November 1914.

56 NAZ A2/3/1 Loc 791/197, Report by the Administrator to the Secretary of BSAC London, 30 November 1914.

57 H Gamwell and M Gamwell, "The History of Abercorn", Northern Rhodesia Journal 5 (5), 1961, p. 254.

58 NAZ A2/3/1 Loc 791/ 197, Report on Abercorn to the Commandant General Northern Rhodesian Forces Salisbury, 28 November 1914. 
Phiri / The role played by Africans in the British war effort in Abercorn District, Northern Rhodesia during the First World War

Map III: The Battle of Kasakalawe

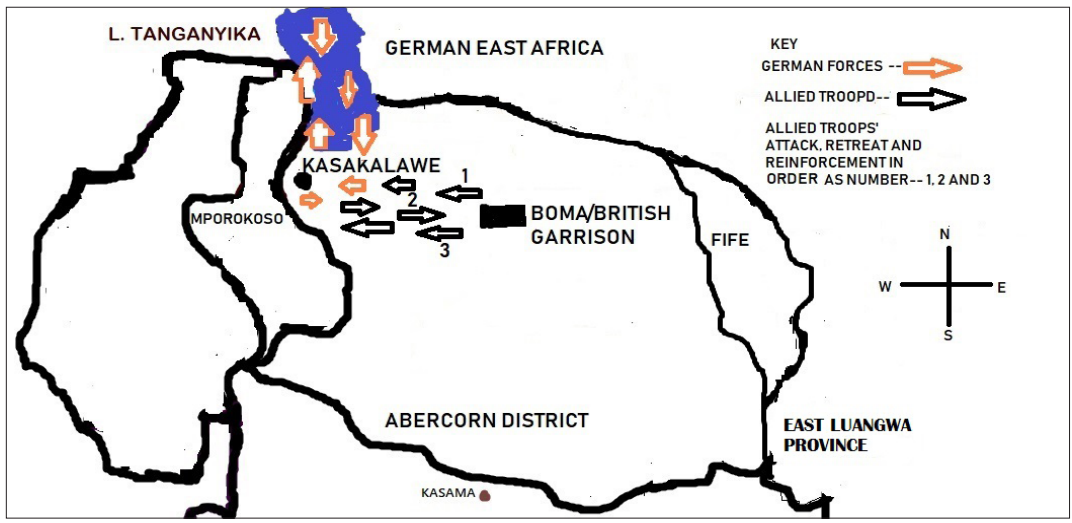

Source: Adapted from Yorke, Britain, Northern Rhodesia and the First World War, p. 69; Zambia Daily Mail, 24 September 2018; National Museums Board, First World War in Northern Rhodesia: Experiences of the Askari-foot Soldiers and Tenga-Tenga War-Carriers .

In all the battles which the Allied troops fought against the Germans, African combatants were a significant factor. This was so because the local people dared to engage the enemy at first-sight without any hesitation..$^{59}$ As with the other battles described above, Africans outnumbered Europeans in this campaign as well. By the time the German General, Lettow-Voeberk, formally surrendered to the British forces at Abercorn on 25 November 1918, to mark the end of the First World War, Allied troops were composed mainly of African soldiers. ${ }^{60}$ On this warfront, European and Indian soldiers were more susceptible to diseases and expensive to maintain. Hence, they were repatriated, leaving the battlefront for the local Africans. ${ }^{61}$

59 NAZ A2/3/4 Loc 794/198, Report by Hodson to the Chief Staff Officer Salisbury, 30 June 1915, p.1.

60 A Samson, "Online International Encyclopedia of First World War, 1914-1918, East and Central Africa", (Berlin: Free University of Berlin, 2016); TH Parson, "Mobilising Britain's Africans Empire for war: Pragmatism vs Trusteeship", Journal of Modern European History 13 (2), 2015, p.189.

61 Samson, "Online International Encyclopedia of First World, 1914-1918 East and Central Africa", p.8; Parson, "Mobilising Britain's Africans Empire for war: Pragmatism vs Trusteeship", p.189. 


\section{AFRICANS AS PRODUCERS AND PROCESSERS OF FOOD FOR ALLIED TROOPS}

Following the outbreak of war in Abercorn, the local people assumed the tasks of producing and processing food for the troops. While able-bodied men were conscripted into the regiment, the majority of women, children, and elderly men took the pivotal role in food production in the villages. ${ }^{62}$

The Mambwe system of cultivation of slash and burn, enabled the remaining population to carry on with farm work even when most of their male folk were enlisted for war services. The local people planted crops such as beans, millet, and cassava.$^{63}$ These crops were preferred by the indigenous people even before the war broke out because they needed less attention between planting and harvesting. The few available male labourers helped in harvesting the crops. Soon after, women and their children processed it. The latter pounded cassava and millet in readiness for cooking. ${ }^{64}$ Women further smoked fish which was caught in nearby rivers and lakes such as Chambeshi, and Saisi. ${ }^{65}$ Usually, women and children took the foodstuffs on their heads and backs to the military camps. ${ }^{66}$

When the demand for food increased in 1915, coercive measures were employed by the authorities to maintain the supply of foodstuffs. At the household level, each family was given a target to process a measurable amount of food, and village headmen supervised the whole process until it was delivered to the administration's depot. ${ }^{67}$ In certain villages like Chipogoma, a small-sized clay pot was used to measure the quantity of food prepared by each household. ${ }^{68}$ Also, Allied forces provided security to the local people who feared to go out to do farming. ${ }^{69}$ This ensured that every local person in Abercorn contributed towards the war.

Besides being important suppliers of foodstuff during the war, women also collected firewood, fetched water, and provided care services to the

62 FENZA I-M-Hi 50, History of Diocese of Mbala; FENZA I-M-IP 16 I16, Father Tanguy Francois Diary, 1914-1927; Interview: Author with ZM Mutembo, freedom fighter, Mbala, 27 March 2019.

63 Interview: Author with J Siame, Mbala, 27 March 2019.

64 Zambia Daily Mail, 24 November 2019.

65 Zambia Daily Mail, 24 November 2019.

66 LM 2/4/58/1 G69/1, Copy of the description of the work done by the Northern Rhodesia police in the 1914-18 war, p. 14; Zambia Daily Mail, 15 November 2018.

67 LM 2/4/58/1 G69/1, Copy of the description of the work done by the Northern Rhodesia police in the 1914-18 war, p. 14; NAZ ZA/7/1/2/9 Box 88, Abercorn sub-District Annual Report the year ending 31 March 1915, 1 April 1915, p. 27

68 Zambia Daily Mail, 24 November 2018; Interview: Author with ZM Mutembo.

69 Interview: Author with ZM Mutembo; Interview: Author with J Sinyangwe. 
Phiri / The role played by Africans in the British war effort in Abercorn District, Northern Rhodesia during the First World War

soldiers. ${ }^{70}$ The latter services included cleaning, cooking, and assisting in caring for the wounded..$^{71}$ Although the local people played a critical role as food suppliers during the war, hunger loomed in the district when the hostilities persisted. Many Africans relocated to the interior of the southern parts of Abercorn where they continued with food production. ${ }^{72}$ During such moments, importation of food for the soldiers from other districts was intensified.

\section{AFRICANS AS PORTERS}

During the First World War, in Abercorn, the British were faced with the challenge of an efficient transport system. The road network from the capital Livingstone to Abercorn, or from Abercorn to other vital districts such as Kasama was in a poor state. ${ }^{73}$ And when the Allied forces began the offensive on the Germans after 1916, the district failed to satiate war needs..$^{74}$ As such, the district had to look back to the capital about 1500 kilometres away for reinforcement. This problem became worse during the rainy season when the only gravel motor road from Kasama to Abercorn became impassable owing to mud, falling trees and grass that blocked it. ${ }^{75}$ Worse still, oxen could be killed by tsetse flies in the region. These conditions impeded any form of mechanised transport to or from Abercorn. Practically, this situation meant that the only transport system near Abercorn was a railway from Livingstone to Ndola on the Copperbelt province. As a result, Kasama was chosen as the main depot for reinforcing Abercorn due to its proximity to Ndola. ${ }^{76}$ Nevertheless, Kasama was equally very far from Abercorn, with 104 kilometres separating the two towns. ${ }^{77}$ However, the soldiers needed war supplies regularly from such distances.

To transport supplies from Ndola to Abercorn through Kasama, British officials used indigenous people as porters or mtenga tenga. ${ }^{78}$ These porters sustained the Allied war efforts in this theatre. For instance, by December 1915, there were more than 5000 combatants at the war front, each of whom

$70 \quad$ Zambia Daily Mail, 15 November 2018.

71 Zambia Daily Mail, 15 November 2018.

72 Zambia Daily Mail, 24 November 2019.

$73 \quad$ NAZ A2/3/1 Loc 791/ 197, Telegram from Northern Rhodesia Administrator to Commandant General, 17 November 1914; National Museums Board, First World War in Northern Rhodesia.

74 The Northern Rhodesia Handbook, p. 18.

75 NAZ A2/3/1 Loc 791/197, Copy of telegram from the Northern Rhodesia administrator to the Commandant General, 17 November 1914.

76 Zambia Daily Mail, 15 November 2018.

$77 \quad$ NAZ, KTN 1/1, 93, Abercorn District Notebook, Volume II, H, p.8.

78 Mtenga tenga was a Chewa term for a porter which colonial administrators mispronunced as tenga tenga. 
required six porters for his needs. ${ }^{79}$ This means that about 30000 porters were recruited to meet the needs of the whole force in December 1915. This entailed that a lot of the local people were enlisted for this war service.

This porterage involved three phases of movement. First, porters walked from the point of production to the collection centre. The next stage involved carrying supplies from the collection centre to the depot, while the last stage involved the movement from the depot to the battlefront where the troops consumed the materials. Therefore, because of these varied distances, porters were also put into three categories. ${ }^{80}$ The first group of porters were actual military carriers who delivered firearms, ammunition, and foodstuffs from the depot to the war front. This class of porters was mainly composed of local people from Abercorn because they knew the terrain of the area very well. Additionally, the indigenous people of Abercorn were also reportedly not timid of the war front like people from other parts of the country. ${ }^{81}$ However, some Africans from other districts, especially the Ngoni of Fort Jameson (Chipata), also worked as first grade carriers. Nonetheless, Africans from Fort Jameson were mainly enlisted for the war campaign in Nyasaland due to the proximity to that country. ${ }^{82}$

The second class was composed of those who carried war cargo from collection centres to the depot at Abercorn, right in the heart of the battlefront. ${ }^{83}$ On the other hand, porters, who ran from one village to another, and from one collection point to the central one, constituted the third grade. Long-distance porters from far off districts like Mumbwa were also part of the third-grade carriers..$^{84}$

It was the third-grade porters who carried the war cargo from the Ndola railway station storage to Chuwutawuta depot in Kasama en route to Abercorn. From Chiwutawuta, Africans carried the load over to Abercorn depot. Each porter carried an average load of between 25 and 30 kilogrammes. ${ }^{85}$ However, as the war demands increased, porters were made to carry loads above the

$79 \quad$ NAZ ZA/7/1/3/9 Box 88, Abercorn sub-District Annual Report the year ending 31 March 1915, 1 April 1915; Breslford, The Story of the Northern Rhodesia Regiment, p. 37.

80 NAZ A2/3/4 Loc 794/198, Memorandum on the Military Porters on the Northern Border, 31 January 1917.

81 NAZ A2/3/4 Loc 794/ 198, Memorandum on the Military Porters on the Northern Border 1 April to 31 January 1917, 1 April 1917.

82 NAZ A2/3/4 Loc 794/ 198, Correspondence from Administrator Wallace to the Secretary of BSACo London. 12 February 1917.

83 NAZ A2/3/4 Loc 794/ 198, Correspondence from Draper CRB A/DC to Administrator at Livingstone, 19 October 1916; NAZ A2/3/4, Loc 794/ 198, Correspondence from Administrator Wallace to Secretary BSACo London, 12 February 1917; NAZ A2/3/4 Loc 794/198 Correspondence from Wallace to the Secretary BSACo, 17 April 1917.

84 NAZ A2/3/4 Loc 794/ 198, Memorandum on the Military Porters on the Northern Border, 31 April 1917.

85 Zambia Daily Mail, 15 November 2018. 
Phiri / The role played by Africans in the British war effort in Abercorn District, Northern Rhodesia during the First World War

standard ones. Carriers were commanded by both Africans and Europeans who punished them for taking long on a journey. Between January 1916 and July 1918, 130701 kilogrammes of various military needs were transported using this route to Abercorn. ${ }^{86}$ There was also transportation of foodstuffs within Abercorn and from neighbouring districts such as Mporokoso which had a water link with the district.

More people were recruited as porters in Abercorn. By December 1914, for instance, the number of people enlisted as carriers in the district was at $3000 .{ }^{87}$ These worked within and outside the district to bring war cargo to the depot at Abercorn. For example, these carried 14144 to 22680 kilogrammes of foodstuffs in early 1915 from the neighbouring districts to Abercorn. ${ }^{88}$ Nevertheless, when the war needs went up from 1916 onwards, the total number of first grade mtenga-tenga who served on this war front from the district together with Fife and Mporokoso was estimated at $11390 .{ }^{89}$

Furthermore, there was a distinct class of porters known as "ambulance carriers" who went to the battlefront to provide medical evacuation services. These carried the wounded for treatment, and the dead for burial. After fireexchange with the enemy, it was usually difficult to spot who had been killed from a distance because such encounters ended in confusion. ${ }^{90}$ Some fighters went missing, while others were found dead or wounded. The wounded could easily be seen as they usually shouted for help due to pain they felt after being shot. These were carried to Kawimbe mission which was designated as the wartime medical treatment centre. ${ }^{91}$ Ambulance porters also searched for dead bodies around areas where fighting took place so that they could be buried. ${ }^{92}$ This task was difficult as most parts of the territory where fights used to take place such as Saisi, or Zombe, were covered by thick bushes, hills and deep ravines. ${ }^{93}$ Although hills and ravines were used by the troops during fire-

86 LM 2/4/ 58/1 G 67/1, Appendices to sir Lawrence Wallace's notes, C: figures regarding water transport, p. 3.

87 NAZ A2/3/2 Loc 792/ 179, Report by District Commissioner Chesnaye to the Administrator on the Affairs of Abercorn and in the Tanganyika District from 20 September 1914 to 31 December 1914, 31 December 1914, p. 8.

88 NAZ A2/3/2 Loc 792/179, Letter from Colonel Commandant General to the Administrator Livingstone, 31 January 1915.

89 LM 2/4/ 58/1 G 67/1, Appendices to sir Lawrence Wallace's notes , B; on summary of first line military porters, p. 2.

90 The fight near Mwazi village is a good example, see, NAZ A4/1/2 Loc 822/208, Vollume II, Report on the Engagement near Mwazi in German East Africa, 30 April 1915, p. 3.

91 Yorke, Britain, Northern Rhodesia and The First World War, p. 102.

92 NAZ A2/3/1 Loc 793/197, Correspondence by Colonel Hodson to the Secretary Livingstone, 27 May 1915, p. 3; NAZ A2/3/1 Loc 791/ 197, Report by Colonel Hodson to the Secretary Livingstone copied to the Chief Staff Officer Salisbury, 28 May 1915, p. 3.

93 NAZ A2/3/2 Loc 197, Correspondence from Colonel Hodson Commandant Office to the Chief Staff Office Salisbury, 22 November 1915. 
exchange for taking cover, it was a challenge to look for dead bodies in such places. All the bodies found were buried according to African traditional burial practices. The local people buried Africans, while Europeans were buried by their fellows, although locals dug their graves. ${ }^{94}$

\section{AFRICANS AS SPIES}

African spies formed an essential component of the army during the First World War in Abercorn. Women, men and children carried out various espionage missions during the war. ${ }^{95}$ When the Germans initially entered Abercorn in September 1914, they regarded local women as being insignificant in as far as the prosecution of the war was concerned. However, as time went by, these women turned to be spies of the British colonial military. In December 1914, for instance, when Germans entered Abercorn through Mambwe village, the British did not know anything about this intrusion but were tipped off by a local woman. Upon noticing the Germans at Mambwe, one local woman secretly went to inform the British soldiers who were on patrol duty near the village. The woman informed the British that she had seen German soldiers at Mambwe village in the company of askari, while others had returned to GEA, possibly to bring more guns. ${ }^{96}$ This information from the anonymous woman was so useful to the British that they immediately went to dislodge the Germans from Mambwe village unannounced. Without the local woman's effort as a spy, it is possible that the Germans could have done damage to both the villagers and the Allied forces in the area. ${ }^{97}$

In 1915, intelligence information from a local man named Jonas Sinyangwe was recorded by Colonel Frederick Arthur Hodson. Sinyangwe was captured and taken as a prisoner by German forces into Tanganyika in December $1915 .^{98}$ Before long, Sinyangwe managed to escape from GEA, and upon his arrival, he informed a British Colonel that the Germans were building a military depot at Mwanzi. ${ }^{99}$ This threatened the security of the district as the location was near Abercorn. The informant also revealed that Germans were scheming to attack and seize Abercorn as soon as they had received more ammunition, they have been waiting for. ${ }^{100} \mathrm{He}$ further disclosed

\footnotetext{
$94 \quad$ Interview: Author with J Sinyangwe.

$95 \quad$ Zambia Daily Mail, 30 October 2018.

96 NAZ A2/3/2 Loc 792/ 179, Letter by Sergeant Chesnaye to Mr Wallace, 16 February 1915.

97 Zambia Daily Mail, 30 October 2018.

98 NAZ A2/3/2 Loc 792/ 197, Copy of Intelligence Information given by Jonas Sinyangwe to Colonel Hodson, 23 December 1915, p. 2

99 NAZ A2/3/2 Loc 792/ 197, Sinyangwe to Colonel Hodson, p. 2.

100 NAZ A2/3/2 Loc 792/ 197, Sinyangwe to Colonel Hodson, p. 2.
} 
Phiri / The role played by Africans in the British war effort in Abercorn District, Northern Rhodesia during the First World War

that a large number of askari with Europeans were marching towards the direction of Fife.

Immediately after receiving the above intelligence information, the Allied forces made changes to their operations. Orders were given to the troops at Fife to keep vigil for a possible attack as the enemy was heading towards that direction. ${ }^{101}$ Patrols were also sent along the border to be on the lookout for the enemy's movements. Sinyangwe's information turned to be accurate as the patrol mission estimated a German party of 800 askari and Europeans heading towards Abercorn border. ${ }^{102}$ Sensing that their clandestine mission had been detected, the German forces instead headed in the direction of Karonga, Nyasaland. ${ }^{103}$ This demonstrates yet again that the local people were instrumental in aiding the Allied war effort. Without such intelligence information from the local people, the Allied forces operating from Abercorn district could have encountered a deadly surprise attack from the Germans.

Because most of the intelligence reports which the local people in Abercorn provided were accurate, the British recruited some of them, including children as scouts in the military. In 1915, for instance, a local Mambwe boy was sent by Sergeant Barnashaw to gather information from the town of Bismarckburg. ${ }^{104}$ The mission was executed without difficulties. In another incidence, in February 1915, locals, only known as Mitimingi and Chambala, were sent by Colonel FA Hodson to gather intelligence information at Bismarckburg. The duo's mission was also a success. They reported on the military equipment they saw at Bismarckburg. ${ }^{105}$

On the other hand, some of the local people in the district were not exclusively employed for such espionage assignments but instead used their initiative to do so. The reason for doing this was that most of the indigenous people living in outlying villages usually received harsh treatment like beating, and food grabbing from the Germans. ${ }^{106}$ This made victims of such treatment assess the party which was worthy supporting with intelligence information during the war. These and those who had officially been recruited by the

101 NAZ A2/3/2 Loc 792/ 197, Sinyangwe to Colonel Hodson, p. 2.

102 NAZ A2/3/2 Loc 792/ 197, Sinyangwe to Colonel Hodson, p.2.

103 NAZ A2/3/2 Loc 792/ 197, Sinyangwe to Colonel Hodson, p. 2.

104 NAZ A2/3/2 Loc 792/ 197, Copy of Intelligence made from two Local Natives from Bismarckburg, 7 February 1915; NAZ, A2/3/1 Loc 791/ 197, Report by Sergeant Barnashaw, 17 February 1915.

105 NAZ A2/3/2 Loc 792/ 197, Copy of Intelligence made by Mitimingi and Chambala to Colonel Hodson, 7 February 1915.

106 NAZ A2/3/1 Loc 791/197, Report from Colonel Hodson to Chief Staff Officer Salisbury, 3 February 1915, p. 1. 
British authorities spied on the Germans movements without many difficulties as they had good knowledge of the terrain and path networks. ${ }^{107}$

However, not all Africans in Abercorn worked for the British as spies as others also spied for the Germans. Confirming this aspect, Sinyangwe narrated to Colonel Hodson how his friend, named only as Tuseko, worked for the Germans as a spy at a fee of about ten shillings. ${ }^{108}$ Before the outbreak of the war, Tuseko was employed as a carpenter at Abercorn BOMA such that he knew the area very well. ${ }^{109}$ This enabled him to effectively carry out espionage missions on behalf of German forces without many challenges.

Furthermore, during the siege of Fort Saisi in 1915, the Germans were guided by a local former farmworker of the same area only known as Chikote. After the attack of Saisi, two local women who lived around the fort and were once at Bismarckburg disclosed that Chikote guided the Germans to the garrison. ${ }^{110}$ They further revealed that Chikote worked for the Germans as their spy in Abercorn. ${ }^{111}$ Chief Manilonga whose locality was within the border was equally used by the Germans for intelligence information over the Allied troops. ${ }^{112}$ In 1915, the District Commissioner of Abercorn became suspicious of some local Mambwe chiefs and headmen of being used by the Germans to spy the Allied troops' movements. ${ }^{113}$ This explains why the Germans used to surprise the Allied forces with well-calculated attacks because they knew the geography of Abercorn through the aid of some local people. For this reason, the British in Abercorn either imprisoned or exiled suspected local people who spied the Allied troops' movements on behalf of the Germans. ${ }^{114}$

107 NAZ A2/3/1 Loc 791/ 197, Correspondence from Hodson to the Chief Staff Officer Salisbury via Livingstone, 30 June 1915.

108 NAZ A2/3/2 Loc 792/ 197, Sinyangwe to Colonel Hodson, p. 2; NAZ A2/3/2 Loc 197, Intelligence information given by Masenga and Miniz, 1 July 1915.

109 NAZ A2/3/2 Loc 792/ 197, Intelligence Information by Jonas Sinyangwe to Colonel Hodson, p. 2.

110 NAZ A2/3/2 Loc 792/ 198, Correspondence from Captain Fair in Abercorn to the Chief Staff Officer Salisbury via Livingstone, 25 June 1915; NAZ A2/3/4 Loc 198, Report from Colonel Hodson to the Staff Chiefs Officer Salisbury via Livingstone, 30 June 1915, p. 1.

111 NAZ A2/3/4 Loc 794/ 198, Report from Colonel Hodson to the Staff Chiefs Officer Salisbury via Livingstone, 30 June 1915, p. 5.

112 NAZ A2/3/2 Loc 792/ 197, Copy of Intelligence information given by two MambwesMasenga and Miniz, 1 July 1915

113 NAZ ZA/7/1/3/9 Box 88, Abercorn sub-District Annual Report year ending 31 March 1915, 1 April 1915, p. 8.

114 NAZ A2/3/2 Loc 792/ 197, Sinyangwe to Colonel Hodson, pp. 2-3; Yorke, Britain, Northern Rhodesia and The First World War, p. 75. 
Phiri / The role played by Africans in the British war effort in Abercorn District, Northern Rhodesia during the First World War

\section{POSTAL RUNNERS}

Africans also worked for the British as postal runners during the First World War in Abercorn. During the war, the Germans from Tanganyika had a trend of seizing communication wires as booty after launching an offensive. ${ }^{115} \mathrm{At}$ times, it was difficult for the British to keep surveillance on the telegraph wires all the time over a wide area such as Abercorn-Fife. The problem of guarding such vital infrastructure became worse during the rainy season when the poles and cables could be destroyed by heavy rains and lightning. ${ }^{116}$

To maintain contacts with other districts during the war, colonial authorities in Abercorn turned to the local people as foot runners of messages. These carried letters to a named destination on foot or bicycle. From August 1914 onwards, districts south-west of Abercorn such as Mporokoso, and Chiengi, were serviced by runners. ${ }^{117}$ Similarly, communication between Abercorn and Mpika was serviced by runners as the Germans had cut the telegraph wires in November 1914. ${ }^{118}$ In 1915, an attempt was made to use motorcyclists as messengers. This proved ineffective as messengers on motorcycles only travelled during daytime due to the bad state of the road. At the same time, foot runners worked both during the day and night time to deliver messages. ${ }^{119}$ Through this system, the BSAC authorities, as far as London, were kept abreast with what was happening in Abercorn during the war.

\section{DESERTION FROM WAR DUTIES}

Although Africans offered various war services, they were alive to the pressing demand of their duties. To avoid being crushed down by their duties, they deserted the columns for their homes. One of the reasons that led to desertion was the unilateral extension of contracts by the military authorities. For instance, askari and first-line carriers could have their contracts extended without their consent as long as the military needed their services. ${ }^{120}$ This

115 NAZ A2/3/1 Loc, 791/ 198, Correspondence between Northern Rhodesia Administrator and the Secretary of the BSA Co London, 4 September 1914.

116 NAZ A2/3/1 Loc 791/ 197, Report by the Abercorn District Commissioner to the Secretary of Livingstone, 31 December 1914, p. 1

117 NAZ A2/3/1 Loc 791/ 197, Report by the Abercorn District Commissioner to the Secretary of Livingstone, 31 December 1914, p. 1; NAZ A2/3/4 Loc 794/ 198, Correspondence from Administrator to Secretary BSACo, London, 10 September 1914.

118 NAZ A2/3/1 Loc 791/ 198, Copy of telegram from Northern Rhodesia Administrator to the Administrator Salisbury, 13 February 1914.

119 LM 2/4/48/1 G 67/1, Copy of the description of the work done by the Northern Rhodesia police in the 1914-18 war, p. 4.

120 NAZ A2/3/4 Telegram of District Commissioner Abercorn to Administrator Livingstone, 28 October 1917. 
made some of the local people not to renew their contracts upon completion of the initial ones. Such servicemen left their stations without certification of discharge from the authorities. ${ }^{121}$

Furthermore, when their role was changed unilaterally, Africans left the columns. For instance, second-grade porters had Abercorn depot as their final destination in the district, while the first-class carriers went to the battlefield as they were actual military porters. At other times, however, second-grade carriers could be turned into first-class porterage. This led to mass desertion by the local people as their responsibility and destination changed without their consent. ${ }^{122}$

In addition, harsh treatment by European supervisors made some Africans desert their columns. After 1916, when the Allied forces began an offensive in GEA, work became strenuous for porters due to long distances and overloads, This led to exhaustion and slow marches by porters thereby making their column commanders whip them as punishment. ${ }^{123}$ As a result, some of the recruited Africans simply abandoned the columns in the bush for their homes. ${ }^{124}$

\section{CONCLUSION}

The above investigation demonstrates that Africans in Abercorn were actively engaged in the First World War through various services which they offered to the belligerent nations. Local men were crucial combatants in the three major battles fought in defence of the district. African fighters also outnumbered their British counterparts. This argument dispels the popular view, which holds that Africans were only recruited as porters during the war. Women and children were key food suppliers of the Allied troops in wartime Abercorn. It has further been established that the people of Abercorn were mainly engaged as firstclass carriers due to their knowledge of the terrain. Contrary to the broader perception that the Africans in Abercorn only helped the British during the war, some of them worked for the Germans at a fee. Lastly, some Africans deserted the columns to avoid being pressed hard by war duties, an aspect which military authorities were not pleased with.

121 NAZ A2/3/4 Loc 794/198, Correspondence of Administrator Wallace to the Secretary of BSACo, London, 12 February 1917; NAZ A2/3/4 Telegram of District Commissioner Abercorn to Administrator Livingstone, 29 October 1916; Interview: Author with ZM Mutembo.

122 NAZ A2/3/4, Loc 794/198, Correspondence of Drapper to Administrator Livingstone, 18 October 1916; NAZ A2/3/4 Loc 794/198, Memorandum on Engagement of Carriers for the Northern Border, by Hugh Marshal visiting Commissioner, 31 January 1917.

123 NAZ A2/3/4, Loc 794/198, Correspondence of Acting District Commissioner of Abercorn Drapper to Administrator Livingstone, 19 October 1916.

124 NAZ A2/3/1 Loc 791/197, Copy of Captain Fair's war Diary, 26 August 1915. 